\title{
RELIGION, MARGINALITY AND POWER RELATIONS: RELIGIOUS CONVERSION AND RELIGIOSITY OF THE INDIGENOUS PEOPLE IN PENYENGAT
}

\author{
Muhammad Ansor \\ State Islamic College of Zawiyah Cot Kala Langsa \\ Laila Sari Masyhur \\ State Islamic University of Sultan Syarif Kasim, Pekanbaru
}

\begin{abstract}
Using a theory of power relation of Michel Foucault, the following research analyzes the behavior of religious conversion in the community of the Indigenous People of Anak Rawa in Penyengat Village, Siak District, hereinafter referred to as the Native People. The research will show that in the middle of the domination of the State and theologians, the community of Indigenous People actualizes power to maintain its identity in the midst of the invasion of new values and culture. To support the argument, the researchers traced the religiosity of the Indigenous People focusing on several events of everyday life such as traditions of marriage, death, and celebration of religious holidays. In addition to adapting to the country's religious traditions they have adopted, this community also modifies the ritual traditions of each religion so that these traditions become a means of preserving their communal identity as a native tribe. The research ultimately shows the interplay between the State and theologians as the dominant group, on the one hand, and the indigenous community as a subjugated group, on the other, in the use of power.
\end{abstract}

Keywords: Indigenous People, Religion, Power Relation

\section{INTRODUCTION}

The Indigenous People is one of the indigenous communities in Riau, in addition to Sakai (Bengkalis), Talang Mamak (Indragiri Hulu), Bonai (Indragiri Hilir), Petalangan (Pelalawan) and Akit (Bengkalis and Meranti Islets). Responding to the urge from the State and theologians the majority of the indigenous communities, such as Sakai, Petalangan and Bonai converted into Islam. However, the Talang Mamak People and the Ingenous People showed different response. The Talang Mamak split in two groups, the followers of the Old and the New Measures. The Old Measures are those who embrace the indigenous religious beliefs, while the New Measures is a term for those who convert to Christianity or Islam. Unlike the Talang Mamak people, the Ingenous People convert into Christians, Buddhists, Confucians, and a small 
number of them to Islam. In other words, among the indigenous communities in Riau, the Indigenous People have converted into various religions.

The Indigenous Community has become the contestation of Buddhist, Confucian and Muslim theologians in the spread of their respective religions. As a result, some thirty years after the State religions were introduced, nominally, the majority of them converted to certain religions. Before that they all still adhered to their old religious beliefs. Except for the success of the strategies the theologians, the Indigenous People's response over the presence of religions was probably the strategy of self-defense.

The following research, in addition to analyzing the power relation that affected the behavior of conversion of the Indigenous People, also identifies the impact of conversion on social changes. The research set out from the argument that religious conversion behavior the Indigenous People of Anak Rawa is an expression of the power relation between the State and the theologians in one hand, and the community of the Indigenous People on the other, in the realization of their respective agendas. The researchers will show that the community of the Indigenous People is active in responding to the domination of the State and the theologians over them.

Using a socio-anthropological approach, the field data was formally collected in 2013. However, the researchers utilized data obtained from interactions with the community in 2009 and 2011. In 2009, the researchers were the Program Coordinators of FPIC (Free Prior Inform Consent) at the Kampar Peninsula with Penyengat being one of work areas. In 2011, the researchers became members of the research facilitated by FKPMR (Communication Forum of Riau Community Leaders) to examine the socio-cultural life of the Indigenous People. The two projects did not discuss the question of the religious life. But the Researchers took the opportunity to collect ethnographic data related to their religious life.

The data collection techniques used were observation, interviews, group discussion, and FGD (Focus Group Discussion). The researchers conducted observations on the Indigenous People by living with them and interviewing the elite society or ordinary citizens to collect information. The researchers discussed with Christian, Buddhist, Muslim and Confucian religious figures involved in the spread of religion to the Indigenous People in Penyengat. The archives and records obtained during field research in Penyengat between 2009 and 2011 were used to frame this paper.

The subject of power relation of and Indigenous People is not a new theme in the social study even though research on the Indigenous People in Penyengat 
is still regarded as a pilot project. The Sakai, Talang Mamak and Petalangan often became subject of research. Study conducted by by Parsudi Suparlan (1995) and Nathan Porath (2002) on the tribe of Sakai. Yonhee Kang (2005) looked into the mantra of Petalangan people. The study that deals with the Indigenous People, among others, was conducted by Timothy P. Bernard (2006) the Double Power Center: the Community and the Nature of Siak and Eastern Sumatra, 1674-1827. However, the study Bernard conducted did not focus on the Indigenous People because the main focus was the classical Kingdom of Siak.

Advanced studies that focused on the power relation between the State and the indigenous communities can be found in the works of Tania Murray Li (2012). Li examined the impact of the State regulation on the indigenous communities in the mountains of Sulawesi, with the use of the theory of power relation and control proposed by Michel Foucault. Christopher Robert Duncan (1998) examined the relationship between ethnicity, Christianity and religious conversion in the indigenous community of on Halmahera Island. Similarly, study conducted by Liana Chua (2012) on religious conversion among the indigenous communities in Malaysia (Sabah and Sarawak) to Christianity. Liana Chua managed to reveal the reasons the native people chose to convert to Christianity rather than Islam which becomes the national identity of Malaysia.

Syamsul Maarif (2012) in his dissertation on the religious dimension of the Ammatoa of Sulawesi elaborated the community's conversion to Islam. Maarif revealed that religious conversion strategies of the Ammatoa community are a response to the insistence of the State to religious conversions. Nevertheless, Islam practiced by this community has its own uniqueness as compared to Islam in general. Maarif said in his study that the Ammatoan religion in an independent religion mixed with Islam.

\section{ETHNOGRAPHIC PORTRAIT OF THE INDIGENOUS OF ANAK RAWA}

\section{The Indigenous People and Their History}

Prior to the arrival of the Malays at the territory of the Indigenous People of Anak Rawa, the region was very isolated and closed. The Malays have acquainted with the Indigenous People since the time of the Kingdom of Siak. At that time the Sultan of Siak needed support of the Indigenous People to establish authority in the area of the East coast of Sumatra. According to Nathan Porath (2002), the Kingdom of Siak gathered the Indigenous People to establish sovereignty in the region. The Indigenous People were known to 
have special skills such as mastering the knowledge about forest resources and having inner power that could be relied upon to expand its power.

Their privileged position in the circle of the Kingdom of Siak was revealed in studies by Timothy P. Bendard and Leonard Y Andaya. Bendard (2006) and Andaya (2008) discussed the critical role of the Indigenous People in international trade activities in the Kingdom of Siak. According to Andaya (2008: 203), at the beginning of the $19^{\text {th }}$ century, the relationship between the Malays and the Indigenous People was formed by mutually beneficial through economic relations. Small groups consisting of the Indigenous People collected forest products for international market demand, while the Malays provided facilities for trade between countries.

Andaya (2008: 217) reported that the alliance between the Malays and the Indigenous People was formalized through a mutually beneficial agreement that both groups headed their respective communities. The Malays, in this context being the elites of the Kingdom of Siak, purchased natural products collected by the Indigenous People. The Indigenous People provided their resources in the form of economic and political power to the Kingdom of Siak. They were also involved as part of the army of the Kingdom in the face of invasion from outside powers. In addition they also played a role in providing spiritual and magical power to the community of the Kingdom. However, this relationship experienced a shift when the Kingdom of Siak was taken over by the Dutch.

The Indigenous People's skills and knowledge of the nature, especially forests, were also used by the Dutch and the Japanese. During the Dutch occupation, the demand for timber for construction and military involved the Indigenous People in such jobs. However, the literature findings showed that the role of the Indigenous People as collectors of natural products and the Malays as traders of such products clearly experienced a shift when the economy in the territory of the Kingdom of Siak was taken over by the Dutch. According to Andaya (2008: 202), the special relationship later changed along with the economic transformation of land from forest products into the agriculture-based economy of plantations in the mid $19^{\text {th }}$ century. Pressures of modernity, the concept of nation-state and transmission of the Malays with an increasingly global economy undermined the position of the indigenous people.

The existence of the Indigenous people experienced a further shift in post independence Indonesia. A political construction formed by the State identified them as an alienated, isolated indigenous community. The term was later changed to the Remote Indigenous Community. Although there was a change in the term, their position remained politically marginalized 
and placed outside the orbit of civilization. It was completely different from the conditions at the time of the Kingdom of Siak, where they had a special position and were respected because of their origin and way of life. At the time of Independence, their way of life is thus considered backwards.

\section{Penyengat and Demographic Conditions}

Penyengat is a village in the District of Sungai Apit, District of Siak Sri Indrapura. Penyengat village consists of three hamlets, Penyengat, Tanjung Pal that served as the administrative center of the hamlet, and Tanjung Mungkal which is located far enough from the two hamlets. Tanjung Mungkal can only be reached through sea routes with a trip of around 90 minutes from Tanjung Pal using a motor boat (pompong).

Penyengat village on the north is bordered by the Selat Panjang Sea, on the South by Dayun Village, on the West by Sungai Rawa Village, and on the East by Teluk Lanus Village. The distance to the Sub-district of Sungai Apit is approximately 63 kilometers, to the provincial capital of Riau about 196 kilometers. The area of Penyengat village is 52,000 ha. The majority of the village is a concession area of big companies, oil palm plantations and industrial plant forests. Only a third of the territory of the is the area of the village. The location of the settlement is located along coastal areas.

The number of households of Penyengat is recorded as many as 301, consisting of $265(88.04 \%)$ male households and $36(11.96 \%)$ female. The number of population is 1,240 , consisting of 625 males (50.40\%) and 615 females (49.60 $\%$ ). Based on the level of education most people in Penyengat (35.56\%) never attended school. The number of people with elementary school education is the second place reaching 19.11 percent. The population that has not yet attended school is $16.94 \%$, and the percentage of people with a threeyear college education and with a bachelor's degree is 0.40 and 0.32 percent respectively of the total population.

The source of livelihood of the population is quite diverse. Based on the data obtained, about a quarter of a percent of the total population of the village is unemployed. A person having a job according to the village census clerk is a person who has economic activities for their families, regardless of the activities. In fact the Indigenous People in the village do not have a steady income. They usually collect timber in the forest. It means that unemployment in the village is much higher than expressed by this data when the profession of housewives and other is classified as 'not working'. 


\section{INDIGENOUS PEOPLE'S RELIGION AND STATE RELIGIONS}

In the past, at least until the program of settlement relocation in the 1980s, almost all of the Indigenous People embraced religious beliefs. They were originally not the adherents of one of the Government's official religions. The religious core of the Indigenous People's is composed of two natures, namely the real nature and the supernatural. According to Mr. Kehong, people can never live off of the supernatural. They believe the presence of supernatural creatures and supernatural powers can affect people's lives. The practice of belief is abstinence and rituals to repel bad luck. All places, such as forests, trees, land, border areas, and etc., have a caretaker. Man must submit to and respect the caretakers. The Ritual of worship is not a plea for mercy, but the release of the vow because, for example, 'God or Gods' have answered their prayer. Mr. Kehong said,

"Worship is not for the forgiving of sins. Worship is to fulfill a vow. When we see fabric of many colors tied to a tree --yellow, black, white-it's actually not to ask for the forgiveness of sins. Because our great grand parents did it for medical treatment, that's where they made a vow to heal diseases; they asked for the help to cure diseases. They knew that God exists. But they asked for permission first by giving the offerings; it is just an intermediary, beneath the God's power there were other powers, like the gods. The gods are definitely there, but where the position of the gods, they don't know. The gods help resolve difficulties. The hardship is from God, they asked for prayers on a deity or occupant of a specific place, when my intention is granted, then I'll do that. For example, when we want to clear the land, we give offerings, ask for help, and after three days, the land can be worked."

For the last three decades, significant changes related to the religion and beliefs of the Indigenous People have begun to change. According to Duncan (1998: 134), residential relocation programs that accompanied the "civilization" project among others are in the form of religious instruction. They welcomed the official religions that came into their lives. Mr. Kehong said, "Religion is a matter of faith each of us chooses. All religions are all for the good path. Islam, Christianity, Buddhism and other religions have a good purpose. Although different, the goal is the same to God." Mr. Kehong likens religious people someone choosing to walk or ride a pompong to accomplish a specific goal. The way is different, while the goal is the same.

Views like this make a difference in religion has never been a problem, both in everyday social interaction and marital matters. The Indigenous People gave freedom to their children to embrace any religion of any kind. They consider conflict that goes on between them is not influenced by religion, but it is strictly 
personal. "Religion," according to Mr. Kehong, "since the beginning, has never told anyone to be evil. The Indigenous People who have no religion never ask others to do evil, let alone God." During the last thirty years, the Indigenous People converted to state religions. In this relatively small village, there are five faiths: Animism, Buddhism, Islam, Confucianism and Christianity. The majority of the population of Penyengat are Christians, reaching 41.53 percent, followed by Buddhists 33.71 percent, Muslim 8.79 percent, and animism 7.66 percent. Each religion has a place of worship. There are one mosque, one temple and two churches. See the following diagram.

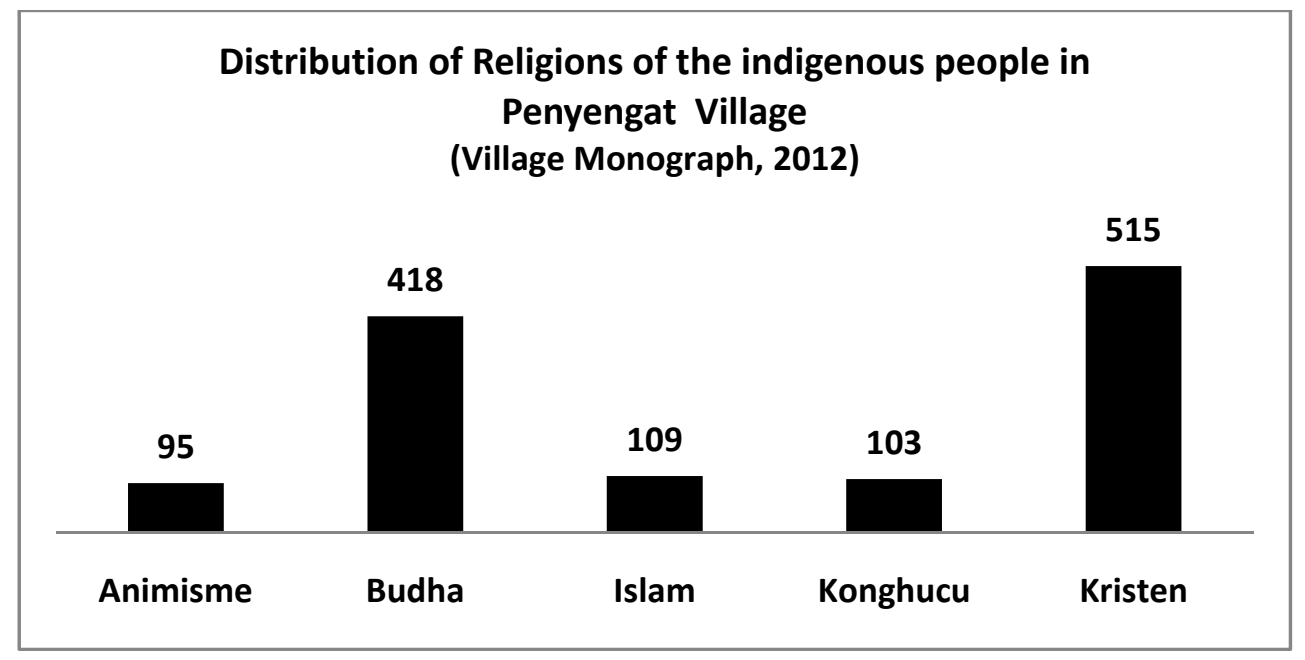

Islam and Christianity were introduced in this village in the 1980s when the Government implemented settlement relocation programs for isolated peoples. People who were interviewed, reported that the HKBP (Harajoan Kristen Batak Protestant) church was built in the village in the 1980s. Buddhism was brought by the local Chinese people. In various places in Bengkalis, Siak and Meranti Islets, most Indigenous People were born from the inter-marriage between them and the Chinese. However, given Confucianism was not recognized until the reform era, in their civil registration it was written as Buddhism. At the time of the population census "requiring a" local religion to be grouped into one of the five State-recognized religions, the Indigenous People preferred to be recorded as followers of Buddhism, despite their adherents of indigenous beliefs.

The presence of the new religions was easily acceptable with varying levels of acceptance. Religious belief remains the core of their religious identity. The acceptance of the official State religions for some people was due to the fact that there were rules that required them to embrace the six State-recognized religions. When they are faced with difficulties to apply for the civil registry administration - such as ID card or certificate of marriage - they keep their 
indigenous religion and have a certain state religion written on their official documents thus allowing them to get married in accordance with one of the recognized State religions.

The insignificance of religion can be seen from reality that in an Indigenous People's household where one can easily find that the members have different religions, although it will never be found in the official documents or reported to the State. This phenomenon can be understood as one of the ways of resistance over State repression. 'On the paper' they have to follow the Government regulations by choosing one of the official religions, but in reality they remain in their original identity, being adherents of the indigenous religious belief. Some Indigenous People we met with said they chose Christianity or Buddhism in order to take care of the administration of official documents.

\section{CONVERSION AND THE POWER OF THE STATE IN RELIGIOUS}

For the Indigenous People, religious conversion is a form of negotiation toward social change taking place around them. The presence of religions in the post settlement relocation programs decades ago has turned them on the limited options: remain in local beliefs with the consequences of an increasingly limited social access; or convert into one of the State religions so that social transformation and access of the rights of citizenship is easier.

Conditions that confront them on the option of converting into one religion can be explained as follows. When they want to get an ID Card $(K T P)$, they are required to choose a State religion. This is due to the fact that their ID card application will not be processed the local government without mentioning an official religion. Before applying for the ID card, a person must first apply for the family card. The latter also requires the mention of a state religion. Surprisingly, although the Constitution recognizes indigenous religious beliefs, the Indigenous People are not allowed to write down their belief on a column on their family card.

A person who does not have an ID card has limited access to some of the rights of citizenship. Alit, while still a student, could not apply for a scholarship offered by the Government of Riau since he did not have a birth certificate. Birth certificates could not be issued because his parents ' marriage was not registered at the local Civil Registry Office. In 2011, several students from an elementary school in Penyengat won an arts contest held at the Sub-district level, but were denied to join the contest at the District level, due to the requirements of the family card. Unfortunately, their parents did not have the 
required document as their wedding was traditionally conducted, and was not recorded at the Civil Registry Office.

In this village, people got their ID and family cards in 2010. The direct impact of civil registration is the emergence of religious conversion behavior. But in some cases, the conversion merely took place administratively. Alit said until now, the people in his village have yet to grasp the true meaning of religion. Alit himself confessed to not fully trust religion as a guide to life. According to him religion does not guarantee a person's behavior for the better. The corruptors in Indonesia, according to the Alit are religious people. But, religious beliefs are not able to prevent them from corruption. When asked why chose conversion to Christianity, he said it was because the Government asked about his religion. Thus, religious conversion is a strategy for the Indigenous People to get more rights as a citizen.

\section{NEGOTIATING IDENTITY IN POST RELIGIOUS CONVERSION 1. Negotiations in the tradition of Marriage}

According to the Indigenous People's tradition, a person has the freedom to choose a spouse. They do not practice arranged marriage by parents. They also do not prohibit marriage across tribal or religious groups. Matter of an arranged marriage, Mr. Kehong reported:

"Many Indigenous People are married to the Javanese, Batak, Chinese, Sumbawa and Flores. They never have dispute over inter-marriage. Their destiny is determined by God. Their customs are not disturbed either. For example, an Indigenous person who has no religion is married to a Javanese Muslim, for most of us, it will be difficult to face the challenge due to difference in religion. But for the Indigenous People it doesn't matter even if they should join the religion of the Javanese Muslim. What comes first is the responsibility and obligation of the marriage. The issue of religion is up to the individual, whether they want to embrace Islam or remain in their indigenous belief. In the tribal parents' view, whatever religion their children embrace, they are still family. They cannot be separated like the sea and the beach. The religions may be different, but our social relations will remain the same.

Marriage in the Indigenous People's community is done before a Batin witnessed by two people. It can take place at the bride's home or at the Batin's. At present, the Indigenous People's marriage is evidenced by a letter of statement signed by the Batin and verified by the village chief, an elderly leader, and two witnesses. This mechanism is actually not known in civil marital recording system in Indonesia. In Indonesia, marriage certificates are issued through 
the Office of Religious Affairs. Among Christians, Buddhists, or Muslims, the marriage contract could be done before a religious leader but must be carried out in accordance with the procedures of the Office of Religious Affairs.

Mr. Abon, a staff at the Local Administration, reported that Indigenous People usually get married by custom, and remarry in accordance with a state religion in order to obtain a marriage certificate from the Government. This is a problem because this mechanism requires that they convert into one of the recognized State religions. He further said:

If we want to record our marriage, first we prepare it in the village. In the Christian religion, we need a letter of marriage blessing from the Church. Then submit it to the Government Civil Registry Office, then they will issue a marriage certificate. If you're a Buddhist, you take a letter of marriage blessing from the temple .... We'll be asked, what our religion is. When we answer it's animism. Then they explain that there are five recognized religions. We are told to pick one ... We get married according to our customs of animism. After that we remarry to get a letter of blessing from the temple. People do not know about animism... Animism does not issue a letter of blessing. It's not valid according to the State. We must have a letter of blessing from a church, temple or Islam. A married person in animism, .. to be able to get a letter of blessing, they should repeat the marriage in (a state recognized) religion ... Many people asked for marriage licenses from the Church. The Church said they had no right to issue marriage certificates, with the exception that the marriage is blessed by the Church.

The above interview shows that its marriage is problematic due to "the absence of recognition of the State. Their customary marriage is not recognized. In order to obtain the recognition of marriage, they have to get it from the Religious Affairs Office, and it applies to Muslims, Christians or Buddhists. It is often the case that a person converting to a certain religion for reasons of wanting to get a letter of marriage blessing, although afterwards they do not observe the religion.

\section{Negotiations in the tradition of Death}

According to the tradition of the Indigenous People, when a person dies, his bode lies in state for three nights before burial. Each night the family and relatives and community members will be staying up and fill the time by playing cards or doing other fun activities. It is not unusual for them, both men and women, to play cards by placing a bet when family members or community members pass away. 
While data collection was in progress in August 2013, two family people died at different times, the wife of Mr. Kehong (Village Head), and Pak Din (a respected shaman in the village). Mr. Kehong's wife converted into a devout Buddhist, while Pak Din is an animist, although in his ID card it is written as Buddhism. For three nights, Mrs. Kehong's dead body lay in state. Festive atmosphere could be seen where community members stayed up late as an expression of respect for the dead. For three nights, people in his home did various activities that merely for entertainment or gambling. On one night, the researchers were staying up, joining the people playing a local game. But they (researchers) could no longer continue after $3 \mathrm{a} . \mathrm{m}$. The researchers chose to sleep next to the corpse of Mr. Kehong's wife, while in the same group of people are playing cards, betting 10 thousand to 50 thousand until dawn.

Ponton, a community leader, said that the event is an expression of last respect to the corpse before funeral. He said a month earlier, when his mother died, his mother's corpse lay in state for seven nights. People gave a tribute in the same way. It is interesting to note that Ponton is a devout Muslim, although on his ID card, he is a Buddhist. People who attended the event came from different religious backgrounds.

The diverse religious conversions among the Indigenous People do not break the bonds of their collectivity and is clearly expressed in the funeral tradition. In Penyengat, the cemetery complex is for various different religious followers in one location. When burying the body of Mr. Kehong's wife, the researchers saw that the burial area for Muslims, Christians, Buddhists and Animists was located in one complex. Abok Agustin, the Penyengat Village Secretary said that the reason to locate the funeral in one location despite different religions indicates their religious harmony.

\section{Negotiations in the Celebration of Religious Holidays}

Two or three days before Muslims celebrate the Idil Fitr, the Indigenous People organized the seven-night likur. This is the 'holy' day for them. The Sevennights of likur is believed to be the day on which the spirits of their ancestors come back to their home. Therefore, to welcome the important moment, they hold a celebration party by eating or drinking all night long, or giving food offerings in front of their respective houses or under the trees on the streets.

On the afternoon of the 26th day of Islamic fasting month, the Indigenous People prepare dishes, fish, chicken, pork and whatever type of food they can provide. Some families make spicy sour dishes, fried pork or beef rendang, vegetable, or any other foods according to their economic 
capabilities. In the evening, at around 8 p.m., they begin to visit each other. The host would invite guests to eat dinner. Parents buy new clothes for their children. The youth usually use the occasion for throwing a typical party of the Indigenous People. In the middle of the night, some of them drink liquor. There is no distinction between men and women in the celebration.

The Seven-night likur is not only in celebrated in the village of Penyengat. The Indigenous People in Rupat (Bengkalis), Rangsang Island (Meranti Islets) and Tanjung Selokop (Pelalawan) also celebrate it. It is interesting to trace the historical roots of the seven-night likur, especially when associated with the fact that they celebrate it on the 27th night of Ramadan (Islamic fasting month). Unfortunately, the Indigenous People in Penyengat are not willing to give explanation about the origins of the feast of likur.

The fact that adherents of animism have a day of celebrations was shown by sociologists and anthropologists. Emile Durkheim, Clifford Geertz, Brian Morris, as well as other sociologists or anthropologists analyzed the Indigenous People's belief system based on their system of rituals. In this case, their indigenous religion is also expressed in the ritual of their holy day.

The likur feast is not only celebrated by those who embrace a local religion. People who have already converted into one of the official State religions also celebrate the ceremony of the seven-day likur. Of the 47 families who celebrated the likur in 2013 (about half a month before the researchers arrived), adherents of Christianity, Buddhism and Confucianism were preparing for the feast. The researchers did not find a Muslim family on the night of the celebration of the seven-day likur. Nevertheless, the tradition of visiting each other on the holy day is not limited to only certain religions, but also done by the Muslims.

The tradition of celebrating each other's big day is done by adherents of different religions. During Idil fitr holiday in the village, the researchers could obviously feel the festive atmosphere in some Muslim households. The researchers joined a group of teachers who visited each other during the Idil fitr holiday. One of them was Alit, a Christian. When a Muslim village secretary invited the villagers to lunch at his house for lebaran (Muslim feast), the researchers found out that people who came were not only Muslims.

How religious holidays are celebrated a family which consists of many different religions is interesting to explore. Alit is unmarried and still living with his father (closer to Confucianism) and his mother who is a Buddhist. Hendry, one of his older brothers had embraced Islam due to marriage. Her sister converted to Christianity, also because of marriage. In Alit's family, there is a Buddhist family member (mother), a Christian, a Muslim, and a Confucian, 
but they are all united by the identity as the Indigenous People who all are convinced of the importance of preserving the traditions of their ancestors. During a Chinese holiday, Alit always prepares in his home to welcome the feast. When Christmas comes, he chooses to join his brother at home to celebrate it. When the researchers visited Hendry's house, they found Alit, his mother and his sister there joining Hendry celebrating the Idil Fitr.

Alit said that he was proud of his multi-religion family, and of the fact that they can celebrate the feast of all religions and get along well. Pak Hok, Alit's father, said that he did not question his children's conversion to any religion, as far as there is one of them who still embraces the ancestors' belief (Confucianism). According to Pak Hok, other religions are not paying attention to the ancestors, but if there is family member who still embraces Confucianism or Buddhism, later when he dies, he will find a way to pay a visit to his family. Pak Hok, although his religion is closer to Confucianism, enjoyed listening to taped sermons by Zainuddin MZ.

\section{THOSE WHO MARGINALIZE (ARE MARGINALIZED): A THEORETICAL CONTRIBUTION}

Previous discussion shows the negotiation of identity of the Indigenous People regarding their religious conversion and behavior during religious holidays, as expressed in the tradition of weddings, funerals, and celebrations of religious holidays. In the following section the researchers will focus on analyzing how these religious practices contribute to explain the pattern of relationship between the power to marginalize and those marginalized. According to James C. Scott (1990), the relationship between the marginalized and those who have power to marginalize always form a resistential relationship. In contrast to Gramsci (1996) who put the marginal party as targets of hegemony, Foucault argued that marginalized parties are not in the passive position at all. According to Foucault (1977: 213), power is scattered everywhere. The difference is whether or not it is actualized. In addition, the difference in the desire to actualize the power also influences the difference of effects of power on an individual (1977: 215).

Power relations according to Foucault (1994: 344-345) occur due to the differentiation of social systems, the different goals in the community, the attainment of objectives, the instruments and forms of social institutions. Related to the difference of social systems, the phenomenon is thus clearly seen on the mindset between countries and theologians as the dominant power on the one hand, and tribal communities on the other. The State has the power to define what is civilized and what is not. The instruments of civilization 
are formulated by the state and its apparatuses (intellectuals, humanists, theologians and the like) to determine that persons outside the criteria are not civilized. This is for Foucault (2002) similar to how healthy people (doctors) make a specific instrument to define about being insane and insanity. Crazy people, according to doctors are those who do not qualify as healthy people. Meanwhile the crazy people themselves are unable to actualize power; doctors have absolute power. In Madness and Civilization, Foucault asked what if the logic is reversed: a crazy man who defines what is healthy and what is not.

The phenomenon of the Indigenous People of the Anak Rawa is constructed as a community lacking civilization, essentially with regard to the difference between their conceptualization and that of the State. One of the indicators of being civilized defined by the state is practicing a State religion. Because the State has access to actualize power over the definition formulated, tribal communities are forced to follow the State's conception of being civilized. The field data indicated that without any religion, the tribal community has its own standards of morality and being civilized. Similarly, there is a big difference between their definition and that of theologians. Theologians believe that happiness in life is following a certain religion whole-heartedly and thus denying the conception of happiness without the State religion.

Marginal communities have always had the power. The dynamics of religious conversion of the Indigenous People showed their strategy in actualizing power. Their seemingly acceptance of the conception of the theologian and the state on the need to be civilized obtained through religion. Meanwhile, simultaneously they express resistance over the conception. They question why they should embrace one of the State religions. However, they have their own definition of religiosity. Religious celebrations have served as an exclusive space for the religion in question, for example, anyone without restricted religious differences can join any religious celebration. This phenomenon is, in the view of James C. Scott (1990), a technique of subordinate group to express their resistance against the dominance they experience.

According to Foucault (1994: 344), the difference in the means of achieving goals also leads to power relations. For the Indigenous People, the expression of gratitude to the unseen (God, gods, ancestral spirits, etc) is an expression of thanks for wishes granted, not a plea for forgiveness for the act of sin. Sin in the view of the Indigenous People will not be eliminated by asking for forgiveness from God, gods or ancestors because it involves evil deeds we commit against fellow human beings. If a person steals, for example, he cannot ask for forgiveness from God, but from people who suffer the crime. Therefore, the sinner should apologize to the people that he had stolen from 
as an expression of remorse over the crimes committed.

Similarly, differences in social institutions also have an effect on power relationship between the pattern of marginal communities and those who marginalize them. In this case, the institution of State is recognized to have almost absolute power in shaping social behavior of the Indigenous People. The State, through the bureaucracy, has the ability to exclude someone who does not follow the criteria formulated by the State. Without an ID card, for example, a person is not recognized as a citizen. They will be denied of their rights of citizenship. For tribal communities who have no social institution as powerful as the State, then the available option is to conform to the will of the State.

Yet, they have their own strategy in actualizing power through social institutions at their disposal. They realize that social cohesiveness must not be removed due to religious differences. Consciously, they struggle to keep space to mingle, taking off each political faith and blending themselves into communal identity as the Indigenous People. The events of marriage, death, celebration of religious holidays serve as their social institutions that keep social space being blocked by religious differences. Such phenomenon shows that amidst the dominance of superior groups, they have a strategy to bring the power of defense within the framework of communal identity. Although it could result in weakening their criteria about the definition of the Indigenous People, the efforts are made in order to preserve their identity in the midst of the pressure of the dominant power against them.

\section{CONCLUSION}

Based on the above discussion, the researchers drew several conclusions. First, the conversion of religion among the Indigenous People correlates with how the State and theologians actualize power. The State formulates criteria for being civilized and defines that the Indigenous People are outside the orbit. This is also related to the view of theologians who look at happiness and civilization can only be reached through religion. In such situations, the Indigenous People are led to the necessity of religious conversion.

Second, religious conversion has an impact on the pattern of significant social changes. The researchers analyze the behavior of everyday life related to weddings, funerals, and celebrations of religious holidays. Conversion of religion requires them to leave behind the inherited ancestral traditions and to adapt to new religious doctrinal conceptions. But they offer a creative formulation which allows them to include the ancestral traditions being 
practiced in the new religion.

The researchers recommend that the Government and theologians stop using excessive power in shaping the social behavior of the Indigenous People. Power approach used in shaping the social behaviour of the Indigenous People will often result in resistance. The Government and theologiand need to formulate steps to the recognition the existence of their cultural identity. Instead of imposing a particular religion, the Government should facilitate the Indigenous People to be themselves.

\section{BIBLIOGRAPHY}

Andaya, Leonard Y., 2008. Leaves of the Same Tree: Trade and Ethnicity in the Straits of Melaka. Honohulu: Hawai University Press.

Bernard, Timothy P, 2006. Pusat Kekuasaan ganda: Masyarakat dan Alam Siak \& Sumatera Timur, 1674-1827. Seri Monograf Pusat Penelitian Kebudayaan dan Kemasyarakatan UNRI, Pekanbaru, Vol 2 No 2 September.

Budiman, Hikmat (ed.), 2005. Hak Minoritas: Dilema Multikulturalisme di Indonesia. Jakarta: Tifa dan Interseksi Foundation.

Chou, Cynthia, 2005. Indonesian Sea Nomads Money, Magic, And Fear Of The Orang Suku Laut. London and New York: Routledge.

Chua, Liana, 2005. The Christianity of Culture: Conversion, Ethnic Citizenship, and the Matter of Religion in Malaysian Bornoe. New York: Palgrave Macmillan, 2012.

Data Kependudukan Desa Penyengat Tahun 2012. dokumen desa, tidak dipublikasikan.

Duncan, Christopher Robert, 1998. Ethnic Identity, Christian Conversion and Resettlement Among the Forest Tobelo of Notheastern Halmahera, Indonesia. A Dissertation of Yale University.

Foucault, Michel, 1982. Afterword: The Subject and Power. Dalam H.L. Dreyfus and P. Robinow (ed.), Michel Foucault: Beyond Structuralism and Hermeuneutics. Brighton: Harvester.

Foucault, Michel, 1991. Governmenality. Dalam G. Burchell, C. Gordon dan P. Miller (ed.), The Foucault Effect: Studies ini Governmentality. Chicago: University of Chocago Press.

Foucault, Michel, 1994. Essential Works of Foucault 1954-1984. P. Robinow (ed.). Frence: The New Press.

Foucault, Michel, 2002. Kegilaan dan Peradaban: Madness and Covilazation. Yogyakarta: Ikon. 
Foucault, Michel, and Gilles Deleuze, 1977. "Intellectuals and Power", dalam Language, Counter-memory, Practice: Selected Essays and Interviews. D.F. Bouchard (ed.), New York: Cornell University Press.

Gomes, Alberto G., 2007. Modernity and Malaysia: Settling the Menraq Forest Nomads. New York: Routledge.

Gramsci, Antonio, 1996. Selection from the Prison Notebooks, New Delhi: Orient Longman.

Kang, Yoonhee, 2005. Untaian Kata Leluhur: Marjinalitas, Emosi dan Kuasa Kata-kata Magi di Kalangan Orang Petalangan Riau. Seri Monograf Pusat Penelitian Kebudayaan dan Kemasyarakatan UNRI, Pekanbaru, Vol 1 No 1.

Li, Tania Murray, 2012. The Will to Improve: Perencanaan Kekuasaan dan Pembangunan di Indonesia, Terj. Hary Santoso dan Pujo Semedi, Yogyakarta: Marjin Kiri.

Maarif, Syamsul, 2012. Dimension of Religious Practice The Ammatoans of Sulawesi, Indonesia. A Dissertation of Arizona State University.

Milner, Anthony, 2008. The Malays. West Sussex: Willey-Blackwell.

Monograf Desa Penyengat Tahun 2010, dokumen desa, tidak dipublikasikan.

Porat, Nathan, 2002. A River, A Road, an Indigenous People and an Entangled Lanscape in Riau, Indonesia. Dalam Bijdragen tot de Taal, Land en Volkenkunde, on the Road the Social Impact of New Road in Southeas Asia, Leiden, 158 No 4. Hal. 769-797

Rab, Tabrani, 2002. Nasib Suku Asli di Riau. Pekanbaru: Riau Cultural Institute.

Suparlan, Parsudi, 1995. Orang Sakai: di Riau: Masyarakat Terasing dalam Masyarakat di Indonesia. Jakarta: Yayasan Obor Indonesia.

\section{INTERVIEWEES:}

Abet (33), Penyengat Village Chief.

Abok (40), Penyengat Village Secretary.

Apui (35), Penyengat resident.

Aseng (40), Penyengat resident.

Buter (46), Penyengat resident

Din (60), Penyengat Community Leader.

Dum (58), Penyengat Batin Chief and Community Leader.

Ebon (49), Buddhist Leader dan Penyengat resident.

Hamid (40), Penyengat Elementary School teacher.

Henry (34), Former Penyengat Youth Leader.

Kehong (45), Penyengat Community Leader.

Kiat (60), Penyengat Customary Leader. 
Navid (40), Staff at the Local Administration of Penyengat.

Res (49), Penyengat Community Leader.

Wiharsono (33), Head of Tani Wirid Yasin Group of Penyengat.

Yanto (34), Penyengat resident. 